\title{
From the urban metabolism to the urban immune system
}

\section{Article}

Accepted Version

Bristow, D. N. and Mohareb, E. A. (2020) From the urban metabolism to the urban immune system. Journal of Industrial Ecology, 24 (2). pp. 300-312. ISSN 1530-9290 doi: https://doi.org/10.1111/jiec.12919 Available at https://centaur.reading.ac.uk/83296/

It is advisable to refer to the publisher's version if you intend to cite from the work. See Guidance on citing.

To link to this article DOI: http://dx.doi.org/10.1111/jiec.12919

Publisher: Wiley

All outputs in CentAUR are protected by Intellectual Property Rights law, including copyright law. Copyright and IPR is retained by the creators or other copyright holders. Terms and conditions for use of this material are defined in the End User Agreement.

\section{www.reading.ac.uk/centaur}

\section{CentAUR}

Central Archive at the University of Reading

Reading's research outputs online 


\section{From the urban metabolism to the urban immune system}

David N. Bristow ${ }^{1, *}$, dbristow@uvic.ca

Eugene A. Mohareb², e.mohareb@reading.ac.uk

*Corresponding Author, +1 250.472.4814

${ }^{1} \mathrm{PhD}$, Assistant Professor, Department of Civil Engineering, University of Victoria. PO Box 1700, Stn CSC, Victoria, BC V8W 2 Y2

${ }^{2} \mathrm{PhD}$, Lecturer in Sustainable Urban Systems, School of Construction Management and Engineering, University of Reading, Whiteknights, PO Box 217, Reading, Berkshire, RG6 6AH, United Kingdom

Word Count: 6,000 + References, Figures \& Tables

Keywords: urban immune system; sustainable urban systems, resilience and adaptation to climate change 


\section{Abstract}

Urban areas face mounting risks from many sources. Cities pursue myriad tactics to resist, recover from and adapt to shocks and stresses, but little is known about how these approaches relate across the scales of a city nor how cities compare in their abilities. Part of the challenge in addressing these gaps is that the risk to cities is typically studied with an emphasis on one or a few hazards or through the lens of a singular sector. This paper proposes a framework, dubbed the Urban Immune System (UIS) to coalesce and expand industrial ecology research on urban risk management. In the same way that Urban Metabolism (UM) is a unifying framework for urban environmental sustainability, UIS can be a unifying framework for urban resilience, especially related to climate change. Herein, UIS is defined, its many capabilities are dissected and linked to disparate studies; and opportunities for application of the concept are provided. The paper concludes by examining the relationship between UIS and climate change and by identifying those attributes of the UIS that are expected to be of increasing importance under climate change. 


\section{Introduction}

Ehrenfeld (2008) argues that achieving a more scientific link between industrial ecology (IE) and sustainability requires the embrace of complexity science within IE. In so doing emergent properties of the systems of interest within IE, like resilience and adaptation can be studied. In the decade since his paper was released his words have been followed by much important work. One of the primary areas of study is cities, the dominant habitat for our species that now hosts $55 \%$ of the global population according to the UN. Much urban IE study is on resource consumption and its mitigation, with many important works being published in this journal (Fischer-Kowalski, 1998; Kennedy et al, 2007; Barles, 2009; Niza et al, 2009; Pincetl et al, 2016); the urban metabolism (UM) framework has been applied in many of these studies, with the material flow analysis (MFA) approach providing a means to quantify the key sources of greenhouse emissions, amongst other sustainability metrics (Kennedy \& Hoornweg, 2012). Industrial ecological study of the emergent properties mentioned above, resilience and adaptation, were seen by some as "limited and undeveloped" as little as three years ago (Meerow and Newell, 2015). Yet it is evident that complexity studies are progressing important areas of inquiry within IE (Djikema et al., 2015). Further, Linkov et al (2015) argue that a need exists to move resilience from the "buzzword to operational paradigm", much the same way that UM has used MFA to provide a sustainability metric for resource demand.

Reflecting on the advancement of UM in recent years, it has become an essential concept in understanding urban sustainability. UM is popular for communicating urban function, as well as resource demands, drivers and distribution (Newell \& Cousins, 2014). In the industrial ecology realm, MFA-based UM assessment serves as a metric of resource demand that serves to convey the scale of a city's 
dependence on its hinterlands, to which sustainability assessments can be based (Kennedy and Hoornweg, 2012).

This approach largely began with Wolman's (1965) pioneering analysis of resource demands for a hypothetical urban city of one million residents. Wolman focused on understanding how to provide the basic urban services of a potable water supply, safe sewage disposal and clean air. These three services, Wolman proposed, were increasingly threatened as cities simply did what healthy cities do - grow larger and consume more. From an urban resilience perspective, these (and other) urban services are further threatened as cities face new anthropogenic challenges from climate change, rapid urbanization, technology change and malicious acts. This changing hazard context provides much of the increasing motivation for investigating the complexity and risk to cities. The organismic throughput metaphor has been a powerful tool in conveying the scale of impact of cities, and facilitated its communication to a broad audience. The success of this tool for sustainability highlights the void that exists in urban resilience space; can a similar framework simply convey a city's performance in this complex topic, improving its accessibility to decision makers, researchers, and members of the general public?

Building on the approach by Wolman and the UM researchers that have followed, this paper proposes a new concept through which to explore these subjects - the Urban Immune System (UIS). UIS is formally introduced after a brief review of the concept of immunity in the biological sense. After which approaches to study the UIS reveals relevance to all hazards, though we present the approach with an emphasis on natural hazards, such as those driven by climate change. The paper concludes with an examination of UIS's potential role to aid in climate change adaptation. 
The objective is to coalesce and establish a path to help advance methods aimed at quantitatively assessing urban resilience and adaptive capacity from an IE perspective. In so doing, the aim is to more completely integrate the study of urban risks into IE in order to expand its understanding and relationship to UM and other aspects of sustainability and to provide the base of knowledge to eventually inform its complete study through a complex systems theory lens.

\section{Background on immune systems}

Biological and ecological systems and processes are useful for conveying other IE analogies (Graedel and Allenby, 2010). This is apparent in UM, and Industrial Symbiosis and the spreading popularity of the concept of a Circular Economy. Following this approach, we now turn to a review of immunity and health in natural systems to provide a foundation for the remainder of the paper.

Biological immune systems, particularly those of vertebrates, are composed of many interacting components. In the broadest sense they are composed of an innate and adaptive systems. The innate system is inherited and includes physical barriers, such as skin; chemical measures, such as stomach acid, clotting and inflammation; and non-adaptive biological mechanisms to neutralize threats. The innate system is the first stage of defense and when needed, it activates the adaptive system (William, 2016). This latter system, also known as the acquired immune system, includes the ability to learn and keep a memory of how to respond to future similar events. In effect, this ability is one way in which a body can be strengthened and it serves the basis of immunization. A latter process in the immune response after the neutralization of threats is the elimination of waste materials from the system (i.e., the dead cells affected by the threat). 
The health of immune systems are hence partially inbuilt and partially acquired, but they can also be impacted by factors like diet (metabolism) or age. It is thus helpful to be able to assess immune systems. Measurement of the health of biological immune systems is an active area of research. It includes at a minimum, measurement of the quantity and characteristics of white-blood cells, which are the essential agents in killing pathogens (Claus et al., 2016). Such measures are done on healthy individuals to track changes in immune system capability. There are of course other problems that can arise in immune systems, such as immunodeficiency and an over-active immune system (autoimmunity).

Metabolism and immunity in organisms are linked during and following the immune system response. During the response metabolic inputs for growth and some normal maintenance functions are diminished, while immune system metabolic requirements may increase, such as the generation of additional heat at the sites of inflammation. Following the immune system response metabolic intake must also be diverted to restoration, potentially at the cost of growth. It should be noted that characteristics and quantities of metabolic flows impact immune system functioning, and can cause wasteful responses that do not contribute to the overall health of the system (Buck et al, 2017; Schaffler \& Buechler, 2012).

\section{The urban immune system}

Through the lens of biological immunity how cities deal with undesirable and unexpected events can be examined. It is possible to draw comparisons of biological immune components and parts of a city. For example, skin behaves like flood barriers; whereas new construction and emergency response could be compared to aspects of the lymphatic system and T-Cells which likens hazards that activate emergency response to pathogens. Exposure routes like the various vulnerabilities of digestive systems could be compared to vulnerabilities along the path that a flood may follow. The level of damage is a function of the size of the hazard like a dose-response relationship in organisms. It is further instructive, however to 
commence from more fundamental aspects of immunity. This involves consideration of immune system attributes such as innate and acquired immunity, regulation, interaction with the metabolism and the measurement of immunity. For the purpose of this inquiry we begin with a proposed definition of the urban immune system (UIS) as the capabilities that protect a city from undesirable abrupt or slowmoving changes by producing a measurable response in urban hard and soft infrastructure and that includes, especially, changes to the built environment, risk management and the sourcing and use of materials and energy.

For measurement of urban immunity it is helpful to contrast how the UIS can be measured with how the UM is measured. Typically, UM is an assessment of flows by mass, energy content or environmental impact; these generally involve quantification of electricity/fuel consumption, construction materials and greenhouse gas emissions (Kennedy and Hoornweg, 2012). These measures relate cities to the global environmental change brought by their activities. Measurement occurs in absolute quantities, such as total mass flow, and so to fully relate the UM to global environmental challenges requires a comparison, such as a target rate of greenhouse gas emissions per capita.

Similarly, UIS can be measured absolutely, but it is enhanced by measuring it in a relative sense - to hazards. In the same way that an organism's immune system capability is relative to particular pathogens, a city's is relative to different types of risks, and cities tend to only have immunity to the hazards they expect to face in the same way that organisms amass antibodies against antigens they encounter. Understanding risk requires answering the questions: What can happen? How likely is to happen? And, what would be the consequences? (Kaplan and Garrick, 1981). The spectrum of hazards that cities face (i.e., what can happen and with what probability) span from abrupt shocks to slow-moving stresses. The UIS modifies the consequences and can include capabilities that help the city against different threats along this spectrum. For instance, cities that are founded adjacent to major rivers tend to be cities that are 
at risk of damage from flood. The degree of measures taken to address the threat of flood represents the UIS capability to handle flood. To contrast, a city in an arid region without a flood hazard has a low chance of flood and likely has a negligible immunity to flood. Assessing UIS, hence, begins with assessing hazards, then the capability of the UIS, then the residual risk of consequences. Cities can be compared in terms of residual risk or immunity to similar hazards.

Further, immunity can also be measured in a static or dynamic fashion. By this we are not referring to the idea that it can be measured once or measured over time, though it can, but rather that immunity includes both a capability for resistance and a capability to change. This is akin to innate and adaptive response and subsequent healing processes of the biological immune system. This dynamic makes UIS necessarily a resilience concept. This is differentiated from traditional approaches to managing risk in the built environment that focus predominantly on the capability to resist by, for example, building hardened structures (Bostick et al., 2018).

The instantaneous resistance and response capabilities reside on a spectrum. As shown in Table 1, the capabilities also span a cost spectrum. For instance, learning how to respond to future events from past events can take a great deal of study but is relatively inexpensive compared to completing large-scale reconstruction or retrofitting of the built environment, which is both a costly and a lengthy process. At the other extreme, evacuation of a building can occur relatively quickly and inexpensively, while the existing physical protection measures of structures, such as their ability to withstand shaking or wind, also applies quickly but would have been relatively more expensive to implement than evacuation. Further, all of these UIS capabilities can hardly be said to be innate. Cities by and large do not have prescribed immune capability established by an unchangeable blueprint. Instead cities demonstrate an entirely adapted (and therefore acquired) immune system. 
Table 1: Examples along the UIS acquisition thresholds

\section{Cost of acquisition}

\begin{tabular}{|c|c|c|c|}
\hline \multirow[b]{2}{*}{$\begin{array}{l}\text { Rate of application } \\
\text { once in place }\end{array}$} & \\
\hline & $\begin{array}{l}\text { Less costly or } \\
\text { challenging to } \\
\text { implement }\end{array}$ & & $\begin{array}{l}\text { More costly or technically } \\
\text { challenging to implement }\end{array}$ \\
\hline \multirow{2}{*}{$\begin{array}{l}\text { Relatively Low } \\
\text { (delay or lengthy } \\
\text { period of } \\
\text { application) }\end{array}$} & Response lessons & New policies & Reconstruction or retrofitting \\
\hline & $\begin{array}{l}\text { Deployed protection } \\
\text { such as sandbags }\end{array}$ & $\begin{array}{l}\text { Emergency } \\
\text { management (plans } \\
\text { and action) }\end{array}$ & $\begin{array}{l}\text { Actuated protection measures } \\
\text { such as flood gates; debris } \\
\text { management }\end{array}$ \\
\hline $\begin{array}{c}\text { Relatively High } \\
\text { (applies } \\
\text { immediately upon } \\
\text { stressing) }\end{array}$ & $\begin{array}{l}\text { Evacuation of a } \\
\text { building }\end{array}$ & $\begin{array}{l}\text { Failover and backup } \\
\text { measures such as } \\
\text { generators }\end{array}$ & $\begin{array}{l}\text { Physical protection thresholds } \\
\text { of structures }\end{array}$ \\
\hline
\end{tabular}

Beyond considerations of rates and costs of acquisition and application, a third aspect of UIS adaptive immunity relates to the permanence of the acquisition. Plans can be forgotten and infrastructure can degrade with time. Emergency plans and built structures require periodic and unending attention. Of course, all cities are subject to a changing hazard context. There are many reasons, such as urbanization and technology change, but one of mounting concern globally is that of climate change. It is driving widespread changes in both acute shocks and slow-moving stresses. 


\section{Measuring Immunity to acute shocks}

\section{Resistance of the built environment}

Study of building and infrastructure stocks within IE reveals important factors relating to sustainability, such as the potential generation of demolition wastes or barriers to greenhouse gas mitigation (Bergsdal, 2007; Mohareb and Mohareb, 2013). Commonly studied variables of stocks include building types, material intensity and energy intensity. Performing similar studies with an augmented set of variables can allow for an assessment of the acute shock-resistance of the built environment. As with material and energy intensity, the shock-resistance immunity of assets within a given city will vary with factors such as age of construction. In addition, comparative studies of the metabolic and immunity characteristics would then also be possible and could help inform multi-objective design, planning and policy.

The shock-resistance to different hazard loads can in theory be quantified using a variety of measures of risk or consequence of damage. A first-principles approach would be to measure using the limit state approach (Brzev and Pao, 2006; Kulak and Grodin, 2014), also known as load and resistance factor design - an increasingly global standard for structural design. This approach results in a probability of failure given uncertainty in the load (S) and the resistance (R) of the structure (Figure 1). The resistance is the absolute immunity and the safety margin, $\mathrm{Z}=\mathrm{R}-\mathrm{S}$ is the measure relative to the hazard. The probability of the safety margin being less than zero is commonly converted into a standard normal distribution and dubbed the reliability index.

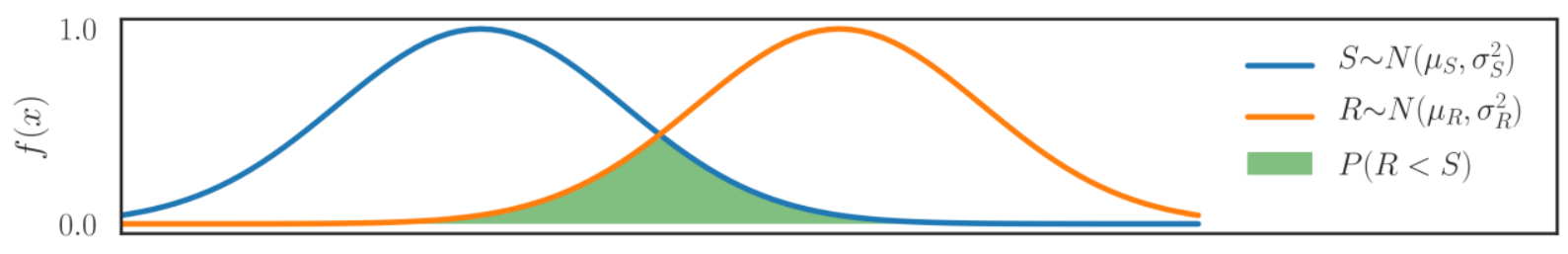

0.0 
Figure 1: Probability of failure, $P(R<S)=P(Z=R-S<0)$, given a normally distributed load $(S)$ and resistance $(R)$.

Just as industrial ecologists have been collecting data on built stocks, so have those concerned with disaster risk. For instance, Porter et al. (2018) assess stock vulnerability using quantitative and judgement-based approaches while Kleist et al. (2006) examine the value of buildings at risk to inform assessments of potential loss. The world housing encyclopedia (world-housing.net) is a growing source of information for risk assessment of buildings (Jaiswal et al., 2010). Much of this work, however focuses on the national or global scale. These types of datasets help inform simulation of disaster consequences in assessment tools such as Hazus and OpenQuake (Kircher, 2006, Scawthorn et al., 2006; Vickery et al., 2006; Pagani et al., 2014) which allow for estimation of damages to the built environment resulting from a variety of natural hazards; work remains to expand these works to different hazards for cities.

\section{Resistance to the cascade effects of failure}

Potentially of equal importance to the direct shock-resistance of structures is the ability to halt or withstand cascade effects that typically follow from initial damage. Increasingly, disaster risks in modern society are not only apparent in the damages caused by realized hazards but in the subsequent cascade of effects that follows. In this regard, national level studies provide foundational research. For instance, the concept of critical infrastructure and the potential cascade of failures from the initial effects of storms, power outages or attacks are illustrative (Ouyang, 2014).

Increasingly the concepts of dependency risk are being applied to cities (Kermanshah et al., 2014; Bristow, 2015, Clark et al., 2018). Here dependencies of the built environment, related technologies and supporting activities, reach their utmost density and complexity. In the same way that ecological network 
Accepted 29 March 2019, Journal of Industrial Ecology

models of UM provide understanding about the structure and functioning of cities, network methods that look at connectivity from a risk perspective are useful for cities. Though there is no standard approach, it is essential, at minimum, to assess the likely spread of failure from one area or infrastructure to the other. An immunodeficient UIS would see the failure spread very quickly across the entire city.

Mechanisms to abate the spread of consequence include network structures with redundancy, diversity, flexibility, and dispersion of assets (Bristow and Hay, 2016). Buffers in the UM also provide some immunity (Bristow and Kennedy, 2013a).

\section{Recoverability}

A related aspect to halting cascades is the ability to hasten recovery. The key aspect of this capability of the UIS is the pace at which the functioning of urban systems returns to normal. In reality this occurs in a spatially explicit manor across urban scales. It is a function of a function of the initial damage, the cascade of effect, the order of restoration activities, the local capacity for recovery, and the availability or delay of replacement materials and equipment, often from beyond the city borders.

This aspect of the UIS is, effectively, the systems engineering concept of resilience as a return to a preevent system state (Haimes, 2009). In practice, cities never return to an identical state post-disaster; however, it is a useful measure against which to assess (Bristow and Hay, 2016, Bristow 2018). Alternative recovery states remains an open question and is related in part to how the UIS adapts to slowmoving stresses, since many small stresses invariably reveal themselves during long recovery processes. 


\section{Measuring immunity to slow changing stresses and UIS dynamics}

\section{UIS depletion over time}

UIS response can diminish over time, much in the same way that an organism's immunity can decline with declining health. For example, shrinking cities (e.g., in USA, Japan, Europe; Schilling \& Logan, 2008; Wiechmann \& Pallagst, 2012; Buhnik, 2010), have observed a decline in metabolic function in a number of neighbourhoods after the loss of manufacturing and migration of population beyond jurisdictional boundaries (Rhodes \& Russo, 2013; Buhnik, 2010). In the case of Detroit, the decline in resource flows resulted in certain neighbourhoods being planned for depopulation through an "urban triage" that entails demolishing or abandoning infrastructure and rezoning previously developed areas as greenspace (Kirkpatrick, 2015). This approach to infrastructural contraction enables the redirection of key resources to more viable neighborhoods, reducing the burden of inevitable degradation of the built environment, such as through corrosion. Parts of the urban organism are intentionally cut off or decommissioned from immune responses that would maintain and restore key urban services as part of cost-saving measures including waste, water, transportation, energy, communications and public lighting. Under climate change, the abandonment of neighborhoods may be accelerated by extreme weather events and sea-level rise.

Further UIS depletion can be inherent in the course of a city's development. Uurban areas founded for the purpose of supporting the extraction of natural resources (e.g., mining towns in Australia, Canada, Russia) can fail to develop a sufficiently diversified economy to maintain infrastructure and services in the long term (Martinez \& Wu, 2009, Table 1; Halseth, 2017; Zemlyanskii, 2011). The resulting 'winding down' that can occur results in urban contraction and associated loss of robustness in UIS response. These cities may have limited time associated with the reserve of the targeted natural resource in which to 
Accepted 29 March 2019, Journal of Industrial Ecology

develop an import-replacement strategy (per Jacobs, 1985, p. 35) and to move away from single-industry status and develop durable institutions to maintain the UIS.

In these examples of slow depopulation, a change in demographics, lifestyle preferences, or the state of keystone employers is the underlying stress. The UIS response can avert the effects by pursuing at least two strategies. The first is coordinated decline as in some Japanese cities or the 'urban triage' in the US (Schilling and Logan, 2008; Buhnik, 2010). Another is economic diversification in advance of the significant decline of a major employment sector.

\section{Long-term UIS dynamics}

Historical and long-term analysis of the socioeconomic metabolism (Krausman et al., 2008) and UM (Kennedy et al., 2008) reveals the expanse of changes in the metabolic needs of society. The changes increased dependency on the products of Earth Systems. The history of UIS is equally revealing. For example, it is observed that the stock at risk has increased over time on pace with urbanization in Shanghai (Quan, 2014). Further, data collected since 1970 suggests that increasing stock development accords with fewer deaths but greater economic loss (Figure 2). It is increasingly common for disasters in developed cities to experience large stock destruction and replacement or refurbishment leading to a high economic cost of damage and downtime. For instance, it is instructive to note that the Japanese earthquake and tsunami in 2011 destroyed approximately $0.2 \%$ of the building and roadway stock of the entire country of Japan (based on quantities from Tanikawa et al., 2014; 2015). This fraction could have been higher if the event were concentrated on a major city. This contrasts developing locales where there tends to be more human exposure but less stock that can be damaged. 

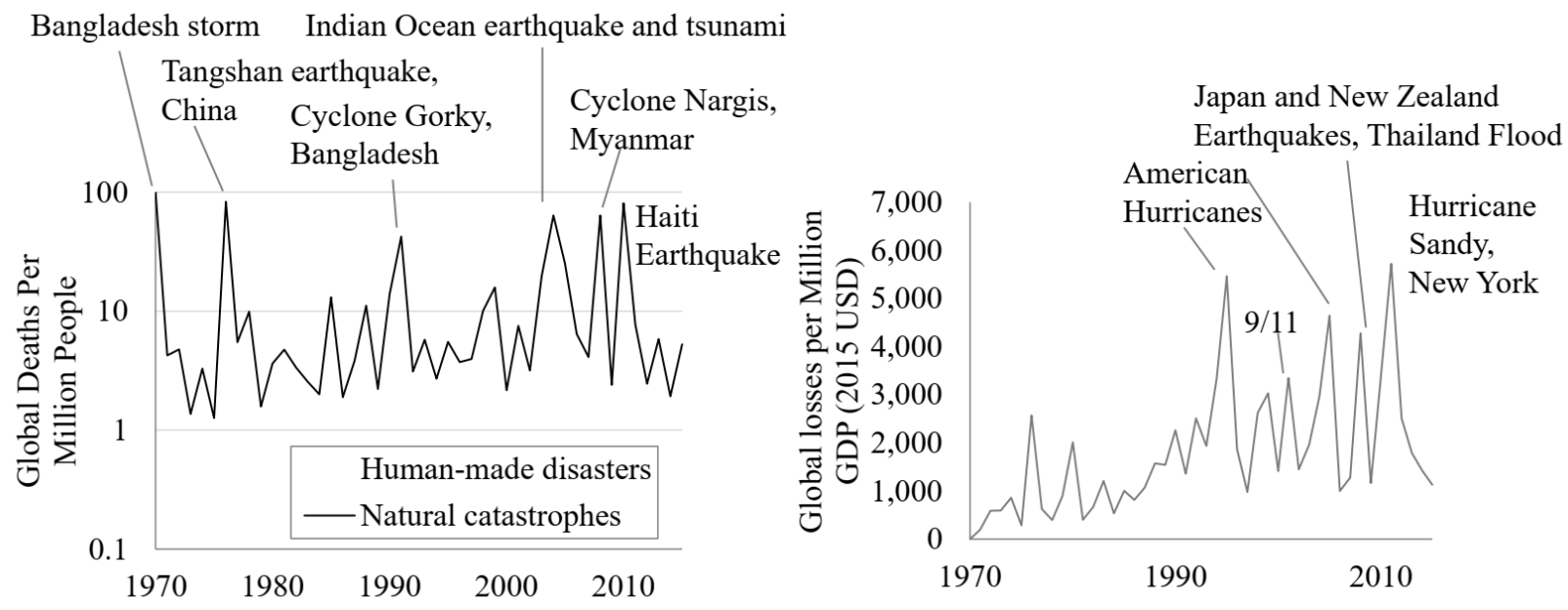

Figure 2: Global disaster deaths and losses (1970-2015). Almost 3 million deaths and \$420 Billion in economic losses since 1970 (30\% insured). Data from from Swiss Re Sigma (swissre.com/sigma).

The difference in outcomes of developed and developing economies is related to the differing value of activities, dependence on metabolic flows and the scale of stocks. A hypothetical disaster timeline of UM for these different ends of the development spectrum is suggested in Figure 3. The metabolism is divided into two components: (i) the metabolic needs for the UIS, which includes response activities and rebuilding, and (ii) all other components of the metabolism. The exact scale, shape and timing of these trends, as well as how these vary with stock characteristics, and hazard behaviour remains an open question. 


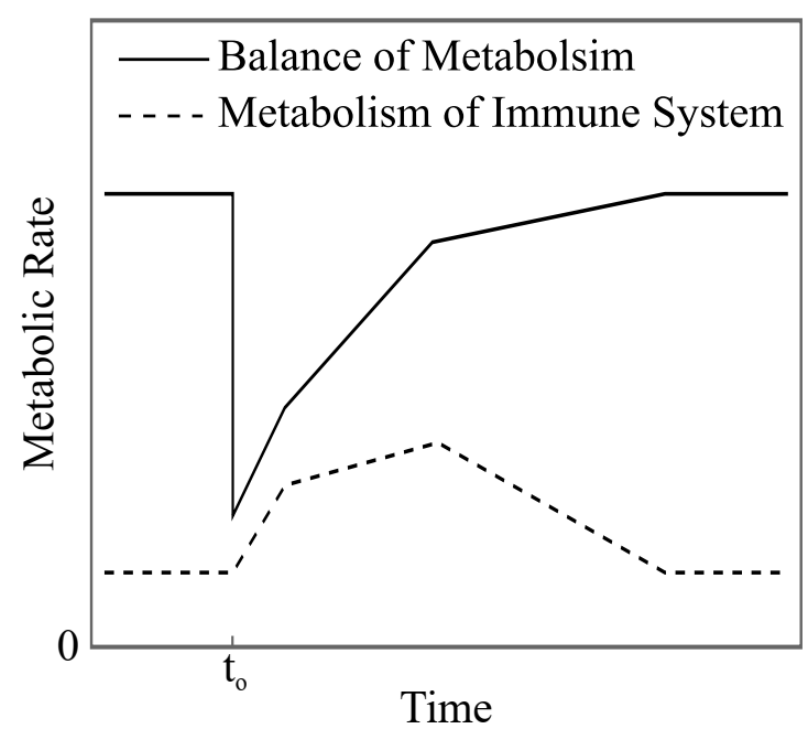

(a) Large stock and high metabolic rate

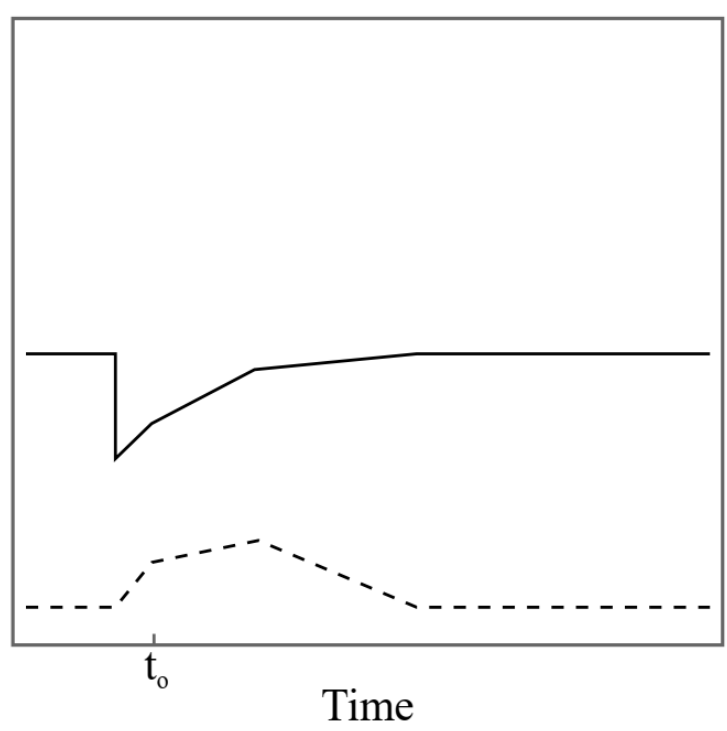

(b) Small stock and small metabolic rate

Figure 3: Hypothetical metabolic flow rate over time after a shock at $t_{0}$. The figure demonstrates expected scale differences, in reality, these shapes and timing of these graphs may also differ, and will also be a function of the specific hazard.

Beyond these suppositions, there also appears to be a history of abrupt UIS changes coupled with a slow evolution. At times in history major losses of the useful material stock of the built environment (e.g., Great Fire of London in 1666, Hurricane Katrina in 2005) drove periods of great revision to UIS practices such as revised building codes, new zoning and roadway standards and enhancement of protectionspecific measures such as levees. In parallel, there is often also a slow moving advance in the immunity of a city through periodic revision and implementation of new practices and policies aimed at addressing residual risks. The abrupt advances are a response to shocks, while the slow moving UIS advances result from either stresses, such as small incidents or from the growing perception of impeding shocks. 
The pace of change of immunity relative to the pace of change of hazards, which is thus far an unexplored area, is expected to be a crucially revealing aspect of the UIS and would benefit from further study. This is partly because it should help reveal how cities extend their capacity to manage risk; this is one part of the resilience concept - graceful extensibility, though it is typically applied to extending capability to unforeseen risks (Woods, 2015). But, also because it is crucial under a nonstationary climate that UIS evolution be better understood.

\section{UIS Regulation}

The unifying concept of UIS dynamics is regulation. For realized shocks the regulation is concentrated on short time-scales, while for stresses and the anticipation of shocks the regulation happens on longer timescales. With either timescale the intention of immune system regulation is the maintenance of a balance between over and under-active immune capability.

No city at present appears to be at risk of what would be considered an autoimmune disease whereby an overreaching immune capability extends to the point that it brings large damage to vast portions of the city. There are of course instances where certain measures are perceived as burdensome or undesirable such as when new safety regulations are introduced or when an addition of a protection measure results in unintended harm to a neighboring property, such as through the diversion of flood water. Instead the present concern for cities is more the risk of an immunodeficiency. How cities differ in their immunodeficiency can be revealed by future UIS comparison studies. 


\section{Immunity at different scales}

The hazards faced by an urban area are not felt uniformly across a city. For example, even after the catastrophic damage experienced by the City of New Orleans from Hurricane Katrina, $37 \%$ of the population was able to remain in place in the months following the event (Kates et al, 2006). Impacts are generally localized to vulnerable areas, while other parts of a city can quickly return to pre-event states. A spatially-explicit hazard continuum that explores capabilities across scales must be considered and acted upon to improve UIS function. Figure 4 illustrates this for the example of flood protection. Further, as mentioned previously, there can be interactions between measures taken in one location on other locations. This further necessitates a need for multi-scale UIS assessment.

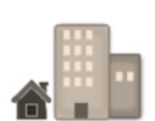

Property Scale

- Property surveys/inspections

- Flood resistance technologies (building envelope barriers, sump pumps)

- Flood resilience technologies (waterresistant finishes, floor tiles in place of carpeting/wood)

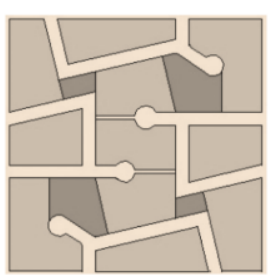

Neighborhood Scale

- Barriers/diversion channels adjacent to local waterways

- Stormwater retention/detention ponds

- Green infrastructure

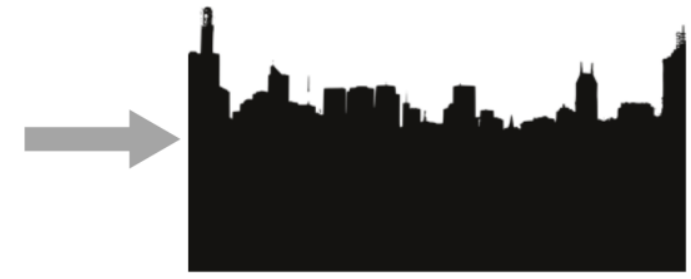

City Scale

- New government departments or mandates to address flood-related planning

- Stormwater management plans

- Tree planting strategy

Figure 4: UIS examples across urban scales for flooding

An interconnected system of implementation that considers immunity measures across scales is essential. City-level policy (though this can also apply to levels of government with broader geographical remits) has the ability to influence the adoption of measures suggested at the finer scales. Neighbourhood-level organizations (community groups, business improvement organizations) can also convene and mobilize the implementation of location-specific measures taken by property owners to improve UIS, as well as 
influence the plans and actions at other scales. This influence can begin at the occupant/property level as well, through community organizing activities and public consultation.

\section{Urban Political Ecology and the UIS}

Urban Political Ecology (UPE) is a research area grounded in the Urban Political Economy tradition of understanding the socioeconomic construct that shapes the physical and social urban environment, along with the agents that deliver the urban areas (Nevarez, 2015); taking an ecological perspective, UPE links this construct with ecological impacts and their associated responses. If contrasted with the UM-MFA research realm, UPE expands beyond MFA's quantitative accounting to provide a deeper examination of the drivers and implications for the social-ecological-infrastructural system (to borrow a term from Ramaswami et al., 2012) of consumption and allocation of resources within cities (Heynen et al, 2007; Newell \& Cousins, 2014). Pincetl et al (2012) put forward the value of integrating an UPE approach to UM-MFA through the inclusion of greater spatial resolution, providing increased lucidity on the systems within the urban entity that drive and allocate resource flows.

UPE has been used to add a new dimension to UM; Gandy (2004) explores the (d)evolution of water system management from municipal to private actors, a regime change whose consequences would not be captured through MFA tabulation. More recently, Pincetl and Newell (2016) explore disparity in Los Angeles' energy and water demand, with consumption by wealthier residents an order of magnitude greater than poorer neighbourhoods. UM-UPE provides new insights that expose threats posed by changes in the socioeconomic system that would otherwise be missed by those engaged purely in exploring the "hard engineering" solutions to unsustainability. 
This leads to the question of which type of approach (UM-MFA or UM-UPE) UIS resembles. If the reader were to allow the simplification of UM-MFA and UM-UPE as being two ends on a spectrum, the former being grounded predominantly in physical sciences methods while the latter drawing more from the social sciences, the UIS methods above align more closely with the MFA side in our conceptualisation. Reflecting on the mapping of the thought traditions identified by Newell \& Cousins (2014), UIS methods discussed here are predominantly quantitative approaches to describing urban capabilities. However, considering the critiques made on UM-MFA above, launching a second stream of UIS-UPE research at the outset is essential but beyond the scope of this forum piece.

We maintain the view that UIS can also be described by the socioeconomic processes that mobilise them, by using an UPE approach that provides deeper consideration of the power structures that exist within the urban system that can both prevent or result in the infrastructural disruption that the UIS aims to combat. Just as power can determine the allocation of resource flows, it can determine the allocation of capacity for protection and recovery. To provide some insight as to how UIS can be explored from a UPE perspective, we defer to examples such as Cutter et al. (2010)'s spatial assessment of disaster resilience through multiple indicators and to Bristow and Bristow (2017)'s analysis of how decision making after an event impacts the pattern of recovery for different parts of a population.

\section{A picture of the UIS}

In summary, UIS is a set of capabilities of a city. It relates to how a city deals with shocks and stresses. An initial set of capabilities defined over the previous sections, and how they can be assessed is summarized in the first three columns of Table 2. The listing begins with general types of capabilities for dealing with shocks. These include construction standards in the existing built form, which dictate the magnitude of hazards that can be withstood with negligible damage - much like the physical barriers of 
the biological immune system. Functional dependency risk management, conversely, pertains to the ability to limit the spread of damage and the effects of damage similar to how a body's lymphatic system can release lymphocytes to stop the spread of infection. As described earlier, these can take several forms, such as redundancies or dispersion of key assets. Closely related to standards and dependency risk management are buffers, such as fuel stores for critical immune response, like a store of antibodies. The final immune capability to shocks is recoverability, without which healing of the city cannot occur. These shock capabilities span from the asset-scale up to infrastructure systems scale and how operations of these systems are managed in and after crises. The final shock capability, identifying and making plans for managing hazards continues this trend to higher-level action and concerns organizational and governance processes. Likewise the capabilities that deal with managing stresses - adapting to changing hazards or modifying hazards, are presently, also largely the domain of human decision making and involve several actors, such as policy makers, engineers, and owners and operators. In this way urban immunity is a system that extends from the built environment through human decision making and organizations.

Table 2: A summary of the UIS capabilities, hazard types that they address, how they are assessed and the relationship to climate change

\begin{tabular}{llll}
\hline Immune capability & $\begin{array}{l}\text { For Shock } \\
\text { or Stress }\end{array}$ & Assessment & $\begin{array}{l}\text { Considerations under climate } \\
\text { change }\end{array}$ \\
\hline Construction standards & Shocks & $\begin{array}{l}\text { Quantity and distribution of } \\
\text { protection thresholds relative to } \\
\text { localized hazard (recall localized } \\
\text { hazard can be modified by slow } \\
\text { moving changes and surrounding } \\
\text { immune system components) }\end{array}$ & $\begin{array}{l}\text { Past standards increasingly } \\
\text { inadequate. Uncertain design }\end{array}$ \\
Functional Dependency \\
Risk Management & Shocks & $\begin{array}{l}\text { Measurement of ability to limit } \\
\text { cascade failure potential against } \\
\text { hazards (e.g., redundancies) }\end{array}$ & $\begin{array}{l}\text { Increasing likelihood of } \\
\text { dependency failures }\end{array}$ \\
Buffers & Shocks & $\begin{array}{l}\text { Expected residence time and } \\
\text { coverage of needs }\end{array}$ & $\begin{array}{l}\text { Heightened importance given } \\
\text { challenges in construction } \\
\text { standards and functional } \\
\text { dependencies }\end{array}$
\end{tabular}


Recoverability Shocks Expected rapidity of recovery of city functioning relative to acute hazard effects

Ability to identify and Both plan for existing hazards

Ability to adapt to changing hazard context

Stresses

Degree to which new hazard levels are addressed for hazards
Heightened importance given uncertainty in future viability of existing developments

Allocation of governance Requires institutions with structures to respond to and plan specialised remit to build local knowledge and plan for vulnerabilities

Useful measure to establish whether construction standards are keeping up with the non-stationary climate

Degree of hazard reduction (e.g., Requires joined-up and global to undiversified economy, safe management of population decline) action on greenhouse gas

mitigation
Stresses to modify hazards

\section{UIS in climate change}

There are many challenges that cities might face due to climate change, such as: increasing frequency of severe storm events; sea-level rise and seawater intrusion; or drought and extreme heat. There may also be indirect changes relating to dependencies on natural resources that become less available either due to their own climate sensitivity, such as harvested products, or due to demand increases, such as materials for low-carbon technologies. In general, the unifying issue is that the risks are varying (Chester and Allenby, 2018). Increasingly the world is moving out of the stability of the Holocene period into a nonstationary Anthropocene that may manifest distinctively different climatological trajectories (Steffen et al., 2018). As a result, the immunity of cities must incorporate more flexibility than has been required of modern cities. 
Mitigation responses by cities to climate change (i.e., addressing UM) must take a strategic and holistic approach so as to avoid undesirable lock-in (Ürge-Vorsatz et al., 2018); lock-in can have potential negative impacts on the UIS. For instance, caution should be used in seeing electrified cars as a panacea to transport greenhouse gas emissions, even in regions with clean electricity grids (Kennedy, 2015), because of supply risk in materials crucial to battery electrodes, such as nickel and cobalt (Turcheniuk et al., 2018). An emphasis on walkable and bikeable cities supported by transit and car sharing builds in resilience to the reliance on these materials, as alternative technologies are researched and developed. The potential UIS impact of other measures to tackle climate change mitigation is increasingly welldocumented (in the form of mitigation actions that also provide adaptation/resilience responsives, see Thornbrush et al., (2013) and Sugar et al., (2014) for examples) and should be included in studies of the state and change of the immunity of cities.

An overview of climate change resilience measures in cities and their primary mapping to UIS capability is shown in Table 3. These capabilities are identified based on discussion observed in the climate change adaptation/resilience literature. For example, natural asset management as proposed by Jones et al (2012) enables urban areas to leverage green infrastructure to both improve their buffers to extreme weather events and mitigate the hazard and improve overall adaptability to changes in climate. Correspondingly, if urban metabolic benefits of green infrastructure are accounted for in MFA studies (as suggested by Perrotti \& Stremke, 2018), this could enable dual consideration of both UIS and UM impacts. Some of these capabilities relate to physical infrastructural approaches, while others focus on management systems. In any case, combinations of capabilities have the potential to create a more robust UIS in responding to climate change. 
Accepted 29 March 2019, Journal of Industrial Ecology

Table 3: Mapping of climate change measures to UIS capabilities

\begin{tabular}{|c|c|c|c|c|c|c|c|c|c|}
\hline \multirow{2}{*}{$\begin{array}{l}\text { Climate Change } \\
\text { Resilience } \\
\text { Measures }\end{array}$} & \multirow[t]{2}{*}{ Sources } & \multicolumn{7}{|c|}{ UIS Capabilities } & \multirow[b]{2}{*}{ Examples } \\
\hline & & $\begin{array}{c}\text { Construction } \\
\text { Standards }\end{array}$ & $\begin{array}{c}\text { Failure } \\
\text { Cascade } \\
\text { Management }\end{array}$ & $\begin{array}{l}\text { Buffers } \\
\text { (in time, } \\
\text { capacity, } \\
\text { storage) }\end{array}$ & Recoverability & $\begin{array}{l}\text { Ability to } \\
\text { identify } \\
\text { and plan } \\
\text { for } \\
\text { existing } \\
\text { hazards }\end{array}$ & $\begin{array}{c}\text { Adaptability } \\
\text { to changing } \\
\text { Hazards }\end{array}$ & $\begin{array}{l}\text { Ability to } \\
\text { modify } \\
\text { hazards }\end{array}$ & \\
\hline $\begin{array}{l}\text { Upgrading } \\
\text { engineering } \\
\text { design } \\
\text { thresholds }\end{array}$ & $\begin{array}{l}\text { (Sandink et } \\
\text { al., 2016) }\end{array}$ & • & & & & & & & $\begin{array}{l}\text { Intensity-duration- } \\
\text { frequency curves w/ } \\
\text { consideration of } \\
\text { climate change } \\
\text { scenarios used in } \\
\text { stormwater } \\
\text { management } \\
\text { infrastructure design }\end{array}$ \\
\hline $\begin{array}{l}\text { Safe-to-fail } \\
\text { Design }\end{array}$ & $\begin{array}{l}\text { (Kim et al., } \\
2017 \text { ) }\end{array}$ & & $\bullet$ & & & & & & $\begin{array}{l}\text { Vegetated bioretention } \\
\text { basins adjacent to } \\
\text { roadways; bioswales }\end{array}$ \\
\hline $\begin{array}{l}\text { Infrastructure } \\
\text { Asset } \\
\text { Management }\end{array}$ & $\begin{array}{l}\text { (Meyer et al., } \\
2010 \text { ) }\end{array}$ & & & $\bullet$ & & & • & & $\begin{array}{l}\text { Climate change-revised } \\
\text { flood mapping of } \\
\text { sensitive infrastructure }\end{array}$ \\
\hline $\begin{array}{l}\text { Natural Asset } \\
\text { Management }\end{array}$ & $\begin{array}{l}\text { (Jones et al, } \\
2012 \text { ) }\end{array}$ & & & • & & & $\bullet$ & • & $\begin{array}{l}\text { Urban wetland } \\
\text { identification, } \\
\text { characterisation, and } \\
\text { monitoring }\end{array}$ \\
\hline $\begin{array}{l}\text { Operational } \\
\text { Resilience } \\
\text { Planning and } \\
\text { Implementation }\end{array}$ & $\begin{array}{l}\text { (Bristow and } \\
\text { Hay, 2016) }\end{array}$ & & $\bullet$ & & $\bullet$ & & & & $\begin{array}{l}\text { Adding redundancies in } \\
\text { dependencies of } \\
\text { operations }\end{array}$ \\
\hline Mainstreaming & $\begin{array}{l}\text { (Sharma and } \\
\text { Tomar, } \\
\text { 2010) }\end{array}$ & & & & & & • & & $\begin{array}{l}\text { Incorporation of } \\
\text { climate change } \\
\text { planning as a matter of } \\
\text { course in subnational } \\
\text { disaster management } \\
\text { planning }\end{array}$ \\
\hline $\begin{array}{l}\text { Low Carbon } \\
\text { Resilience }\end{array}$ & $\begin{array}{l}\text { (Heidrich et } \\
\text { al., 2013) }\end{array}$ & & & & & & • & • & $\begin{array}{l}\text { Joint community } \\
\text { adaptation and } \\
\text { mitigation plans }\end{array}$ \\
\hline Collaboration, & (Rosenzweig, & & $\bullet$ & & $\bullet$ & $\bullet$ & $\bullet$ & & Consultative integration \\
\hline
\end{tabular}


Accepted 29 March 2019, Journal of Industrial Ecology

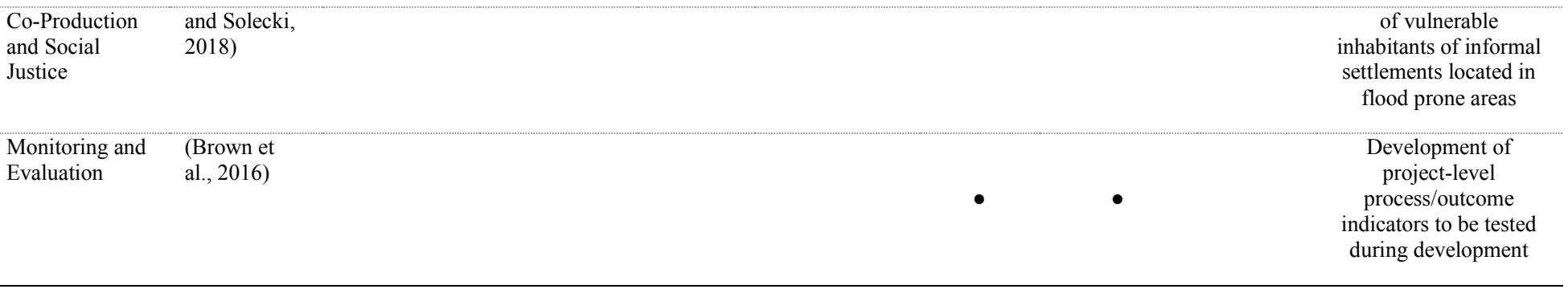


The assessment of UIS interactions with the rest of the city could, however, go further. Dynamic stock models, for example, inform understanding and planning for urban metabolic changes (Müller, 2014). The parameters from these models, could be disaggregated to account for metabolic flows associated with different motivating factors, such as immunity and low carbon retrofits. Further, risk assessment approaches for the stock and metabolic flows, similar to those proposed for critical materials, could inform modeling on the distribution of causes for stock turnover. Bristow and Kennedy (2013b) provide a possible approach for discerning the division of different types of metabolic flows in cities, but without consideration of the UIS as one of these types.

More generally, the capabilities of the UIS defined in Table 2 each include unique considerations under a changing climate (rightmost column). In particular, the non-stationarity makes it difficult to establish construction standards as has been the conventional practice within engineering. This makes measures of the degree to which stocks are keeping pace with realized hazard levels important (see "ability to adapt to a changing hazard context" in the table). The changing hazards further increase the vulnerability in functional and resource dependencies. The result being that buffers, recoverability and the ability to modify hazards are likely to become increasingly important aspects of the UIS.

As shown in Table 2, The capability relating to modification of hazards requires large coordinated activity, hope for this measure may be found in urban networks. The accelerating growth of city networks is seen as an important factor in the environmental action (Acuto, 2016). Similar joined-up action will ideally lead to action and learning pertaining to immunity. UIS studies that allow for the development of metrics of immune capabilities, as well as city comparisons (e.g., resilient-c.ubc.ca, $\underline{\text { resin-cities.eu) }}$ can help advance the knowledge base for informing action within such networks. 


\section{Conclusion}

Cities universally adopt systems of recovery allowing their functioning as centers of social organization, human interaction and economic activity. Identifying and communicating the capabilities that mobilize these systems is vital in ensuring that they are maintained and strengthened to face the mounting challenges cities face vis-a-vis climate change, population dynamics, health and security. In the tradition of analogies that have demonstrated how systems can become more sustainable, such as UM or industrial symbiosis, the UIS provides a framework in which a common conception and language around risk and recovery can be developed, allowing easier comparison and explanation to a wider audience.

The UIS is proposed as a concept related to, but distinct from UM. It is differentiated by its emphasis on identifying and quantifying risk, as well as its scope that looks beyond energy and material stocks and flows. UIS is the set of capabilities that a city uses to manage risk in the built environment. The concept builds on and extends a variety of studies into urban risk such as reliability thresholds of engineering design and functional dependency risk. Thus far, it highlights areas of incomplete or missing knowledge, such as urban recoverability, and UIS regulation over short and long timescales. Overall, the UIS concept has the capacity to unify these areas of inquiry as well as augment UM methodologies.

Climate change is a key motivator of this work. In analyzing the UIS relative to climate change, two important aspects are apparent. First, that uncertainty of hazards means that static engineering design thresholds are increasingly inadequate. While this means revising thresholds or building in an adaptive manner are important, the time lags and uncertainty necessitate the tracking of thresholds within and across cities to begin formulating a means of comparing action in cities. This is of further importance due to the dependency risks of cities. Secondly, that buffers, recoverability and hazard modification through 
climate change mitigation are of utmost importance. In future it is expected that much can be learned from detailed quantitative UIS assessments along the measures discussed here to help further support and enhance urban resilience action while locating common trends and potential tradeoffs against different objectives, such as a sustainable UM, or at different spatial scales.

\section{References}

Acuto, M., 2016. Give cities a seat at the top table. Nature News, 537(7622), p.611.

Barles, S. (2009), Urban Metabolism of Paris and Its Region. Journal of Industrial Ecology, 13: 898-913. doi:10.1111/j.1530-9290.2009.00169.x

Bergsdal, H., Bohne, R.A. and Brattebø, H., 2007. Projection of construction and demolition waste in Norway. Journal of Industrial Ecology, 11(3), pp.27-39.

Bostick, T.P., Connelly, E.B., Lambert, J.H. and Linkov, I., 2018. Resilience science, policy and investment for civil infrastructure. Reliability Engineering \& System Safety, 175, pp.19-23.

Bristow, D.N. and Bristow, M., 2017, October. Recovery planning for resilience in integrated disaster risk management. In Systems, Man, and Cybernetics (SMC), 2017 IEEE International Conference on (pp. 2643-2648). IEEE.

Bristow, D.N. and Hay, A.H., 2016. Graph model for probabilistic resilience and recovery planning of multi-infrastructure systems. Journal of Infrastructure Systems, 23(3), p.04016039.

Bristow, D.N. and Hay, A.H., 2016. Graph model for probabilistic resilience and recovery planning of multi-infrastructure systems. Journal of Infrastructure Systems, 23(3), p.04016039.

Bristow, D.N. and Kennedy, C.A., 2013a. Urban metabolism and the energy stored in cities: Implications for resilience. Journal of Industrial Ecology, 17(5), pp.656-667. 
Bristow, D.N. and Kennedy, C.A., 2013b. The energy for growing and maintaining cities. Ambio, 42(1), pp.41-51.

Bristow, D.N., 2015. Asset system of systems resilience planning: the Toronto case. Infrastructure Asset Management, 2(1), pp.15-22.

Bristow, D.N., 2018. How spatial and functional dependencies between operations and infrastructure leads to resilient recovery. ASCE JIS, in press.

Cutter, S.L., Burton, C.G. and Emrich, C.T., 2010. Disaster resilience indicators for benchmarking baseline conditions. Journal of Homeland Security and Emergency Management, 7(1).

Brown, C., Shaker, R.R. and Das, R., 2016. A review of approaches for monitoring and evaluation of urban climate resilience initiatives. Environment, Development And Sustainability, pp.1-18.

Brzev, S. and Pao, J., 2006. Reinforced Concrete Design: a practical approach, 3rd Edition. Pearson Prentice Hall.

Buck, M.D., Sowell, R.T., Kaech, S.M., \& Pearce, E.L., 2017. Cell 169, 570- 586.

Buhnik, S. (2010). From Shrinking Cities to Toshi no Shukushō: Identifying Patterns of Urban Shrinkage in the Osaka Metropolitan Area. Berkeley Planning Journal, 23(1). Retrieved from https://escholarship.org/uc/item/2df4m61b

Buhnik, S., 2010. From Shrinking Cities to Toshi no Shukushō: Identifying Patterns of Urban Shrinkage in the Osaka Metropolitan Area. Berkeley Planning Journal, 23(1). Retrieved from https://escholarship.org/uc/item/2df4m61b

Chester, M.V. and Allenby, B., 2018. Toward adaptive infrastructure: flexibility and agility in a nonstationarity age. Sustainable and Resilient Infrastructure, pp.1-19. 
Accepted 29 March 2019, Journal of Industrial Ecology

Clark, S.S., Chester, M.V., Seager, T.P. and Eisenberg, D.A., 2018. The vulnerability of interdependent urban infrastructure systems to climate change: could Phoenix experience a Katrina of extreme heat?. Sustainable and Resilient Infrastructure, pp.1-15.

Claus, M., Dychus, N., Ebel, M., Damaschke, J., Maydych, V., Wolf, O.T., Kleinsorge, T. and Watzl, C., 2016. Measuring the immune system: a comprehensive approach for the analysis of immune functions in humans. Archives of toxicology, 90(10), pp.2481-2495.

Dijkema, G.P., Xu, M., Derrible, S. and Lifset, R., 2015. Complexity in industrial ecology: Models, analysis, and actions. Journal of Industrial Ecology, 19(2), pp.189-194.

Ehrenfeld, J.R., 2004. Can industrial ecology be the "science of sustainability"?. Journal of Industrial Ecology, 8(1- 2), pp.1-3.

Fischer- Kowalski, M. (1998), Society's Metabolism. Journal of Industrial Ecology, 2: 61-78. doi: $\underline{10.1162 / j i e c .1998 .2 .1 .61}$

Gandy M, 2004. Rethinking urban metabolism: water, space and the modern city, City, 8:3, 363-379, DOI: $10.1080 / 1360481042000313509$

Graedel, T.E. and Allenby, B.R., 2010. Industrial ecology and sustainable engineering. Upper Saddle River, NJ:: Prentice Hall.

Haimes, Y.Y., 2009. On the definition of resilience in systems. Risk Analysis: An International Journal, 29(4), pp.498-501.

Halseth, G. (Ed.), 2017. Transformation of Resource Towns and Peripheries. London: Routledge.

Heidrich, O., Dawson, R.J., Reckien, D. and Walsh, C.L., 2013. Assessment of the climate preparedness of 30 urban areas in the UK. Climatic Change, 120(4), pp.771-784. 
Jacobs, J. 1985. Cities and the Wealth of Nations. New York, NY: Vintage Books. ISBN 9780394729114.

Jaiswal, K., Wald, D. and Porter, K., 2010. A global building inventory for earthquake loss estimation and risk management. Earthquake Spectra, 26(3), pp.731-748.

Jones, H.P., Hole, D.G. and Zavaleta, E.S., 2012. Harnessing nature to help people adapt to climate change. Nature Climate Change, 2(7), p.504.

Kaplan, S. and Garrick, B.J., 1981. On the quantitative definition of risk. Risk analysis, 1(1), pp.11-27.

Kennedy, C. and Hoornweg, D., 2012. Mainstreaming Urban Metabolism. Journal of Industrial Ecology, 16: 780-782. doi:10.1111/j.1530-9290.2012.00548.x

Kennedy, C., 2015. Key threshold for electricity emissions. Nature Climate Change, 5(3), p.179.

Kennedy, C., Cuddihy, J. and Engel- Yan, J., 2007. The changing metabolism of cities. Journal of industrial ecology, 11(2), pp.43-59.

Kermanshah, A., Karduni, A., Peiravian, F. and Derrible, S., 2014, October. Impact analysis of extreme events on flows in spatial networks. In Big Data (Big Data), 2014 IEEE International Conference on (pp. 29-34). IEEE.

Kim, Y., Eisenberg, D.A., Bondank, E.N., Chester, M.V., Mascaro, G. and Underwood, B.S., 2017. Failsafe and safe-to-fail adaptation: decision-making for urban flooding under climate change. Climatic Change, 145(3-4), pp.397-412.

Kircher, C. A., Whitman, R. V., and Holmes, W. T. (2006). "HAZUS Earthquake Loss Estimation Methods." Natural Hazards Review, 7(2), 45-59. 
Kirkpatrick, L.O., 2015. Urban Triage, City Systems, and the Remnants of Community: Some "Sticky" Complications in the Greening of Detroit. Journal of Urban History 2015, Vol. 41(2) 261-278 DOI: 10.1177/0096144214563503juh.sagepub.com

Kleist, L., Thieken, A.H., Köhler, P., Müller, M., Seifert, I., Borst, D. and Werner, U., 2006. Estimation of the regional stock of residential buildings as a basis for a comparative risk assessment in Germany. Natural Hazards and Earth System Science, 6(4), pp.541-552.

Krausmann, F., Fischer- Kowalski, M., Schandl, H. and Eisenmenger, N., 2008. The global sociometabolic transition: past and present metabolic profiles and their future trajectories. Journal of Industrial ecology, 12(5-6), pp.637-656.

Kulak, G.L. and Grondin, G.Y., 2014. Limit States Design in Structural Steel, 9th Edition. Canadian Institute of Steel Construction.

Meerow, S. and Newell, J.P., 2015. Resilience and complexity: A bibliometric review and prospects for industrial ecology. Journal of Industrial Ecology, 19(2), pp.236-251.

Meyer, M., Amekudzi, A. and O'Har, J., 2010. Transportation asset management systems and climate change: adaptive systems management approach. Transportation Research Record: Journal of the Transportation Research Board, (2160), pp.12-20.

Mohareb, E.A., Mohareb, A.K., 2014. A comparison of greenhouse gas emissions in the residential sector of major Canadian cities. Canadian Journal of Civil Engineering, 41:285-293, https://doi.org/10.1139/cjce-2013-0465.

Müller, E., Hilty, L.M., Widmer, R., Schluep, M. and Faulstich, M., 2014. Modeling metal stocks and flows: A review of dynamic material flow analysis methods. Environmental science \& technology, 48(4), pp.2102-2113. 
Accepted 29 March 2019, Journal of Industrial Ecology

Nevarez, L. (2015). Urban Political Economy. In The Blackwell Encyclopedia of Sociology, G. Ritzer (Ed.). doi:10.1002/9781405165518.wbeosu013.pub2

Newell, J.P. and Cousins, J.J., 2014. The boundaries of urban metabolism: Towards a political-industrial ecology. Progress in Human Geography, [online] 39(6), pp.702-728. Available at: $<\underline{\text { http://phg.sagepub.com/cgi/doi/10.1177/0309132514558442>. }}$.

Niza, S. , Rosado, L. and Ferrão, P. (2009), Urban Metabolism. Journal of Industrial Ecology, 13: 384405. doi:10.1111/j.1530-9290.2009.00130.x

Ouyang, M., 2014. Review on modeling and simulation of interdependent critical infrastructure systems. Reliability engineering \& System safety, 121, pp.43-60.

Pagani, M., Monelli, D., Weatherill, G., Danciu, L., Crowley, H., Silva, V., Henshaw, P., Butler, L., Nastasi, M., Panzeri, L. and Simionato, M., 2014. OpenQuake engine: an open hazard (and risk) software for the global earthquake model. Seismological Research Letters, 85(3), pp.692-702.

Perrotti, D., \& Stremke, S. (2018). Can urban metabolism models advance green infrastructure planning? Insights from ecosystem services research. Environment and Planning B: Urban Analytics and City Science. doi: $10.1177 / 2399808318797131$

Pincetl, S., Bunje, P. and Holmes, T., 2012. An expanded urban metabolism method: Toward a systems approach for assessing urban energy processes and causes. Landscape and urban planning, 107(3), pp.193-202.

Pincetl, S. , Graham, R., Murphy, S. and Sivaraman, D. 2016, Analysis of High- Resolution Utility Data for Understanding Energy Use in Urban Systems: The Case of Los Angeles, California. Journal of Industrial Ecology, 20: 166-178. doi: $10.1111 /$ jiec.12299

Pincetl, S. and Newell, J.P., 2017. Why data for a political-industrial ecology of cities?. geoforum, 85, pp.381-391. 
Porter, K.A., Jaiswal, K.S., Wald, D.J., Greene, M., Comartin, C., 2018. WHE-PAGER Project: A new initiative in estimating global building inventory and its seismic vulnerability. The 14th World Conference on Earthquake Engineering, October 12-17, 2008, Beijing, China.

Quan, R., 2014. Risk assessment of flood disaster in Shanghai based on spatial-temporal characteristics analysis from 251 to 2000 . Environmental earth sciences, 72(11), pp.4627-4638.

Ramaswami, A., Weible, C. , Main, D., Heikkila, T., Siddiki, S., Duvall, A., Pattison, A. and Bernard, M. (2012). A Social- Ecological- Infrastructural Systems Framework for Interdisciplinary Study of Sustainable City Systems. Journal of Industrial Ecology, 16: 801-813.

Rhodes, J. and Russo, J., 2013. Shrinking 'Smart'?: Urban Redevelopment and Shrinkage in Youngstown, Ohio, Urban Geography, 34:3, 305-326, DOI: 10.1080/02723638.2013.778672

Rosenzweig, C. and Solecki, W., 2018. Action pathways for transforming cities. Nature Climate Change, $8(9)$, p. 756.

Sandink, D., Simonovic, S.P., Schardong, A. and Srivastav, R., 2016. A decision support system for updating and incorporating climate change impacts into rainfall intensity-duration-frequency curves: Review of the stakeholder involvement process. Environmental Modelling \& Software, 84, pp.193-209.

Scawthorn, C., Flores, P., Blais, N., Seligson Hope, Tate, E., Chang, S., Mifflin, E., Thomas, W., Murphy, J., Jones, C., and Lawrence, M. (2006). HAZUS-MH Flood Loss Estimation Methodology. II. Damage and Loss Assessment. Natural Hazards Review, 7(2), 72-81.

Schaffler A. and Buechler, C., 2012. CTRP family - linking immunity to metabolism. Trends in Endocrinology and Metabolism April 2012, Vol. 23, No. 4. http://doi:10.1016/j.tem.2011.12.003 
Accepted 29 March 2019, Journal of Industrial Ecology

Schilling, J. and Logan, J., 2008. Greening the Rust Belt: A Green Infrastructure Model for Right Sizing America's Shrinking Cities, Journal of the American Planning Association, 74:4, 451-466, DOI: $10.1080 / 01944360802354956$

Sharma, D. and Tomar, S., 2010. Mainstreaming climate change adaptation in Indian cities. Environment and Urbanization, 22(2), pp.451-465.

Steffen, W., Rockström, J., Richardson, K., Lenton, T.M., Folke, C., Liverman, D., Summerhayes, C.P., Barnosky, A.D., Cornell, S.E., Crucifix, M. and Donges, J.F., 2018. Trajectories of the Earth System in the Anthropocene. Proceedings of the National Academy of Sciences, p.201810141.

Sugar, L., Kennedy, C. and Hoornweg, D., 2013. Synergies between climate change adaptation and mitigation in development: case studies of Amman, Jakarta, and Dar es Salaam. International Journal of Climate Change Strategies and Management, 5(1), pp.95-111.

Tanikawa, H., Fishman, T., Okuoka, K. and Sugimoto, K., 2015. The weight of society over time and space: A comprehensive account of the construction material stock of Japan, 1945-2010. Journal of Industrial Ecology, 19(5), pp.778-791.

Tanikawa, H., Managi, S. and Lwin, C.M., 2014. Estimates of lost material stock of buildings and roads due to the Great East Japan Earthquake and tsunami. Journal of Industrial Ecology, 18(3), pp.421431.

Thornbush, M., Golubchikov, O. and Bouzarovski, S., 2013. Sustainable cities targeted by combined mitigation-adaptation efforts for future-proofing. Sustainable Cities and Society, 9, pp.1-9.

Turcheniuk, K., Bondarev, D., Singhal, V. and Yushin, G., 2018. Ten years left to redesign lithium-ion batteries. 
Ürge-Vorsatz, D., Rosenzweig, C., Dawson, R.J., Rodriguez, R.S., Bai, X., Barau, A.S., Seto, K.C. and Dhakal, S., 2018. Locking in positive climate responses in cities. Nature Climate Change, 8(3), p.174.

Van Beers, D. and Graedel, T.E., 2003. The magnitude and spatial distribution of in-use copper stocks in Cape Town, South Africa. South African Journal of Science, 99(1-2), pp.61-69.

Vickery, P. J., Lin, J., Skerlj, P. F., Twisdale Jr., L. A., and Huang, K. (2006). HAZUS-MH Hurricane Model Methodology. I: Hurricane Hazard, Terrain, and Wind Load Modeling. Natural Hazards Review, 7(2), 82-93.

Wiechmann, T. and Pallagst, K. M. (2012), Urban shrinkage in Germany and the USA: A Comparison of Transformation Patterns and Local Strategies. International Journal of Urban and Regional Research, 36: 261-280. doi:10.1111/j.1468-2427.2011.01095.x

William, P.E., 2015. Immunity. Johns Hopkins University Press, Baltimore. p.14-19

Wolman, A. (1965) The Metabolism of Cities. Scientific American, 213, 179-190. http://dx.doi.org/10.1038/scientificamerican0965-178

Woods, D.D., 2015. Four concepts for resilience and the implications for the future of resilience engineering. Reliability Engineering \& System Safety, 141, pp.5-9. 